\title{
Pelayanan Pastoral Bagi Anak-anak Buruh
}

\author{
Legia Suripatty
}

\section{PENDAHULUAN}

Demonstrasi yang terus terjadi di Indonesia menjadi semacam "trend" bagi siapapun untuk menyampaikan aspirasi. Demonstrasi sudah menjadi " life style" karena hal ini sudah merambah keseluruh bagian lapisan masyarakat. Salah satu realita yang begitu nampak di depan mata adalah aksi para buruh. Menurut Said Iqbal yang adalah PresidenKonfederasi Serikat Pekerja Indonesia/Presiden Federasi Serikat PekerjaMetal Indonesia demikian :

\begin{abstract}
"Aksi demo buruh yang digelar serentak di sejumlah daerah di Indonesia oleh lebih dari 2 juta pekerja, Rabu (3/10), merupakan bentukekspresikekecewaan para pekerja terhadap pemerintah yang dianggap tidak pekamerespons aspirasi mereka. Tiga hal yang utama dari aspirasi itu adalah terkait penataan sistem kerja alih daya (outsourcing), penghapusan upah murah, dan penyegeraan jaminan sosial, khususnya jaminan kesehatan. Trilogi tuntutan itu bukanlah isu yang baru muncul kemarin, melainkan disuarakan bertahun-tahun oleh pekerja melalui berbagai cara elegan dan demokratisagar diperoleh penyelesaian bijak dari pemerintah (Kompas Sabtu, 6 Oktober 2012).
\end{abstract}

Aksi yang buruh lakukan perlu diperhatikan semua pihak bukan hanya pemerintah saja oleh karena trilogi tuntutan yang diajukan sebetulnya hanya "kulit luar" yang membungkus semua hasrat dan keinginan yang terdalam para buruh. Hal yang menjadi sorotan dalam kajian singkat ini adalah bagaimanakah nasib dari anak-anak para buruh ?apakah mereka layak mendapatkan pendidikan yang pantas seperti anak Indonesia yang lain ? ataukah ini memang sudah "takdir" yang Maha kuasa karena memang mereka dilahirkan dari keluarga buruh sehingga semua keturunan harus menjadi buruh ? ataukah ini memang sudah menjadi cita-cita?

Penulis berterima kasih kepada Pdt. Dr Daniel Sutanto yang lebih membuka worlview serta menstimulir untuk melihat peran pastoral tidak hanya dalam tembok denominasi golongan atau kelompok tertentu tetapi bagaimana Patsoral memberikan kontribusi secara positif dan bernilai dalam kehidupan sosial kemasyarakatan.Sehingga Allah yang Maha Kuasa yang "nun" jauh disana (dalam formulasi teologi) menjadi nyata dalam kehidupan yang ada disini.Fakta tentang kurangnya sumbangsih, gereja, teolog dan orang percaya untuk anak -anak para buruh menjadi sorotan dalam tulisan ini. Dalam tulisan ini penulis akan mengkaji tentang hakekat anak yang didalamnya termasuk 
potret kehidupan buruh anak (apakah mereka memilih menjadi buruh anak atau karena terpaksa melakukan hal ini ataukah karena peran orang tua? ) serta bagaimana pola pelayanan pastoral terhadap kelompok buruh ini.

\section{Realita Kehidupan Buruh Indonesia}

Dalam banyak kajian, buruh memiliki beragam pengertian tetapi kontekslah yang memberikan makna siapakah dan apakah buruh sebenarnya. Menurut KBBI buruh adalah orang yang bekerja untuk orang lain dengan mendapat upah ; pelabuhan ; tambang. Buruh di kategorikan dalam beberapa bagian yaitu Buruh Harian adalah mereka yang menerima upah berdasarkan hari masuk kerja ; Buruh Kasar adalah buruh yang menggunakan tenaga fisiknya karena tidak mempunyai keahlian dibidang tertentu ; Buruh Musiman yaitu buruh yang bekerja hanya pada musim-musim tertentu ; Buruh Pabrik adalah buruh yang bekerja di pabrik; Buruh tambang yaitu buruh yang bekerja dipertambangan ; Buruh tani yaitu buruh yang menerima upah dengan bekerja di kebun atau di sawah orang lain. Dalam pembahasan ini yang menjadi sorotan adalah kehidupan anak-anak para buruh kasar. Lebih jelas tentang apa yang dimaksudkan dengan buruh kasar adalah pernyataan dari Sumarti Saelan demikian :

\footnotetext{
"Buruh atau kuli, tanpa membuka kamus besar bahasa Indonesia menurut pemahaman saya sebuah kata yang secara umum merujuk pada sebuah profesi. Buruh secara umum oleh masyarakat luas adalah ditujukan untuk sebuah profesi atau pekerjaan yang cenderung lebih membutuhkan tenaga dan kekuatan tubuh bukan kemampuan berfikir yang tinggi seperti layaknya seorang pegawai kantoran yang duduk didepan sebuah meja dengan komputer atau alat tulis dan peralatan kantor lainnya. Bahkan cenderung ditujukan untuk menyebut pekerjaan kasar para kalangan bawah yang kadang lebih sering ditujukan untuk pekerjaan yang dilaksanakan secara masal seperti buruh pabrik, buruh bangunan, buruh rumah tangga, kuli panggul dan lain-lain.Yang mana profesi ini memang mayoritas dilakoni oleh orang kalangan menengah kebawah yang merupakan golongan mayoritas orang di Indonesia.Bahasa kasarnya adalah masyarakat miskin.Yang mana sebagian profesi buruh ini tidak membutuhkan tingkat pendidikan yang tinggi atau ijasah dari sekolah dan perguruan tinggi bergenggsi. Yang dibutuhkan hanya kekuatan tenaga dan kemauan (atau keterpaksaan keadaan karena tuntutan ekonomi) dari si pelaku atau calon buruh tersebut ".
}

Rumusan ini menjadi pengertian secara general tentang Buruh.Maka Buruh kasar menjadi kelompok masyarakat yang terpinggirkan atau kelas bawah yang sangat sulit untuk bisa mencapai standart hidup layak.Jika situasi ini memang sudah melekat kepada para buruh, pertanyaan yang muncul adalah bagaimana kehidupan keluarga mereka atau lebih spesifik lagi adalah bagaimana pendidkan anak mereka? Pertanyaan ini diajukan karena hal ini menjadi sesuatu mendasar yang memberi pengaruh terhadap anak. 
Jika dihubungkan dengan pendidikan maka para buruh kebanyakan akan menghindar. Hal ini dikarenakan bukan karena mereka tidak mau anaknya mempunyai pendidikan yang tinggi tetapi karena biaya pendidikan di Indonesia secara khusus daerah perkotaan semakin hari menjadi semakin mahal. Dampak dari hal ini yang pertama adalah begitu banyak anak indonesia yang tinggal di perkotaan harus rela menjadi buruh walaupun usia mereka belum pantas untuk pekerjaan itu. Mereka harus rela kehilangan waktu bermain dan masa kanak-kanak.Catatan dari Purbalingga demikian: "Selama ini banyak anak putus sekolah yang memilih bekerja di plasma industri rambut dan bulu mata palsu Purbalingga". Menurut data ILO bahwa pekerja anak terbesar ada di Indonesia Timur dan Hampir separuh pekerja anak di Indonesia bekerja di sektor pertanian, disusul sektor jasa, kemudian manufaktur. 1,7 juta anak bekerja di daerah yang berbahaya, 688.000 anak menjadi pembantu rumah tangga (Kompasiana.com). Yang kedua, situasi seperti ini membentuk pola pikir orang tua yang berprofesi buruh yaitu yang penting bisa makan hari ini sudah cukup,sehingga profesi buruh menjadi pekerjaan "turunan" seperti kata pepatah "buah tidak jatuh jauh dari pohonnya". Sehingga banyak orang tua yang bekerja sebagai buruh sudah tidak lagi memikirkan lagi pendidikan para anak mereka.

Realita sosial ini menjadi tantangan dalam diri semua anak bangsa apalagi gereja-gereja Tuhan yang ada di Indonesia untuk melaksanakan panggilan sucinya serta mengimplementasikan hukum kasih yaitu mengasihi Tuhan dan juga sesama manusia.waktunya sudah tiba untuk mejadi terang yang dilihat oleh semua orang secara khusus anak-anak para buruh serta menjadi garam yang bisa dirasakan keasinannya dan untuk mencegah kebusukan-kebusukan perlakuan sosial bagi anak para buruh. Orang Kristen, lembaga / Yayasan Kristen dan gereja ada disini di bumi pertiwi Indonesia bukan di tempat yang "nun" jauh disana yang hanya dapat dicapai, dimasuki dan dirasakan dengan janji-janji suci. Karena itu pelayanan pastoral bagi anakanak para buruh dalam bentuk menyembuhkan, menopang, membimbing dan memulihkan adalah bagian atau panggilan hati semua orang percaya dan gereja, ini bukan hanya sebuah program.

\section{Hakekat Anak}

Masa kanak-kanak adalah masa yang penuh dengan kebahagiaan oleh karena hidup kanak-kanak bebas dari gangguan orang dewasa, masa dimana mereka lebih bebas mengekspresikan diri serta mendapat perlakuan-perlakuan yang istimewa.Tetapi sepertinya hal ini hanya menjadi sebuah "dongeng" oleh karena realita kehidupan anak-anak tidak terjadi seperti ini apalagi bagi anakanak para buruh.Permasalahan tentang anak ini bukan baru terjadi sekarang ini tetapi perlakuan yang salah bahkan menyimpang terhadap anak sudah berlangsung lama.Dalam tulisan Kennedy dan Newcombe di paparkan tentang 
kehidupan anak-anak di dunia zaman dulu yaitu anak-anak dijadikan kurban menjadi fenomena secara umum.Para nabi dewa kuno Baal dan isttrinya Astarte pada umumnya melakukan upacara kurban anak-anak sebagai bagian dari ibadah mereka.Dalam zaman Romawi dan Yunani melahirkan anak adalah hal yang sangat berbahaya.Pengguguran bayi dipraktekkan dimanamana.Membuang bayi ditengah hutan atau di sisi gunung untuk dimakan binatang liar atau bahkan mati kelaparan.Menurut tradisi lama paterfamilias (kepala keluarga), keluarga Romawi bukan merupakan kenyataan biologia. Anak-anak diterima ke dalam dunia ini hanya jika keluarganya menginginkannya. Seorang Romawi tidak punya anak; ia mengambil anak. Pembunuhan terhadap anak-anak bukan hanya syah saja tetapi perbuatan ini adalah tindakan yang terpuji. ${ }^{1}$

Permasalahan anak-anak dari masa ke masa terus terjadi walaupn dalam bentuk yang berbeda-beda.Mengapa hal ini terus terjadi?karena pemahaman tentang anak sangat terbatas oleh faktor-faktor socio-kultural dan lain-lain. Maka tidak heran jika anak hanya dipandang sebagai anak bukan manusia.Sokrates berkata: Apa gunanya engkau menggali setiap inci tanah untuk menemukan emas di dalamnya tetapi kehilangan anakmu? karena itu hakekat anak perlu dimengerti oleh semua mereka yang ingin memiliki anak atau bahkan yang sudah memiliki anak secara khusus para buruh.

1. Anak adalah pemberian Allah artinya kehadiran anak dalam kehidupan keluarga semata-mata bukan karena keinginan keluarga atau suami istri tetapi merupakan perkenanan Tuhan. Anak bukan produk atau "ulah" orang tua tetapi Allah ada di dalamnya. Sehingga semua orang yang memiliki anak telah mendapat hak istimewa dan tanggung jawab untuk memelihara dan membesarkan anak di dalam pengenalan akan Allah yang benar.

2. Anak adalah manusia. seorang anak yang lahir dalam keluarga adalah satu pribadi utuh yaitu manusia. Pertanyaan tentang apakah suami isteri melahirkan anak atau manusia ${ }^{2}$ merupakan pertanyaan mendasar bagaimana sikap kita terhadap anak. Melahirkan anak mengandung arti bahwa anak akan terus dalam posisi sebagai anak seumur hidup dan diperlakukan sebagai anak terus-menerus sedangkan melahirkan manusia mengandung arti bahwa anak akan diperlakukan sebagai manusia, tetapi karena berhubung anak alahir dalam keluarga maka dia disebut sebagai anak.

3. Anak adalah anugerah. Anak yang hadir ditengah keluarga adalah pemberian Allah secara cuma-cuma bukan usaha manusia. Walaupun

1 James Kennedy dan Jerry Newcombe, Bagaimana Jika Yesus tidak pernah lahir, (BATAM Interaksara 1999), 22-23

2 Stephen Tong, Membesarkan anak dalam Tuhan, (Jakarta, LRII 2000), 8 
ada banyak orang merasa bahwa kehadiran anak bisa dihasilkan dengan berbagai macam rekayasa genetika atau berbagai cara yang dilakukan para medis tetapi semua masih bergantung kepada tangan Allah. Salah satu bentuk untuk mengerti anugerah Allah dalam keluarga adalah melalui kehadiran anak.

Dari ketiga rumusan tentang hakekat anak maka anak adalah manusia seutuhnya yang berarti bahwa anak adalah ciptaan Allah yang dicipta menurut gambar Allah sebagaimana yang dicatat dalam Kejadian 1:27 "Maka Allah menciptakan manusia itu menurut gambarNya, menurut gambar Allah diciptakanNya dia ; laki-laki dan perempuan, diciptakanNya mereka". Hal ini memberikan implikasi normatif yaitu :

1. Segala hal yang ada pada manusia berasal dari Allah dan eksistensi hidupnya berada dalam kehendak Allah sehingga hanya Allah saja yang berhak menuntut secara mutlak kepada manusia.

2. Manusia harus mempertanggung jawabkan semua hal yang ada pada dirinya karena hanya manusia yang diciptakan secara unik yaitu mempunyai akal budi, suara hati, kemauan, kehendak dan kebebasan. Selain itu juga iman Kristen selalu menekankan kasih dimana kasih itu nyata dalam pribadi Yesus Kristus sehingga hal ini menjadi sesuatu yang dasariah bagi setiap orang yang mengaku dan percaya kepada Yesus Kristus.

3. Jikalau manusia merupakan ciptaan dan objek kasih sayang Allah, maka berlaku : menghormati martabat manusia berarti sekaligus menghormati kemahadaulatan Allah dan sebaliknya tidak mungkin menghormati Allah kalau kita memperkosa martabat manusia.

4. Kalau semua manusia diciptakan oleh Allah dan diselamatkan dari jurang dosa oleh kerahiman Allah, maka semua orang dihadapan Allah adalah sama. Dengan demikian segala bentuk diskriminasi merupakan pelanggaran langsung terhadap martabat manusia.

5. Karena semua orang dihadapan Allah adalah sama derajatnya maka tidak ada orang atau kelompok orang yang begitu saja berhak menguasai orang lain. Itu berarti bahwa setiap kekuasaan manusia atas manusia memerlukan legitimasi.

6. Manusia selalu harus diperlakukan sebagai tujuan pada dirinya sendiri, ia tidak pernah boleh digunakan hanya sebagai sarana untuk tujuan yang lebih lanjut.

7. Manusia tidak pernah boleh dibiarkan apalagi disebabkan menderita apabila dapat dicegah. Penderitaan seseorang tidak pernah boleh menjadi sarana bagi masyarakat atau negara untuk memperoleh suatu keuntungan. 
Maka perlakuan dan perhatian kepada anak merupakan tanggung jawab yang serius.Karena anak adalah manusia yang memiliki potensi moral dan kewajiban kekal sehingga pendidikan anak perlu diperhatikan dengan serius karena pendidikan anak bukan hanya memberi dia makan, pakaian, gizi cukup sehingga tidak sakit. Tetapi bagaimana dengan kerohanian mereka ?Aspek ini adalah fondasi dasar yang harus dikerjakan oleh orang tua.

\section{Buruh Anak}

Secara mendasar anak memiliki hak untuk tumbuh kembang secara wajar.Jika hal ini dihalangi karena hanya sebuah kepentingan apalagi jika anak di pekerjakan belum pada waktunya, maka ancaman itu telah datang.Pengabaian hak anak adalah sebuah pelanggaran hukum tetapi terlebih lagi sebuah ancaman global dan jangkan panjang bagi tumbuh kembangnya suatu bangsa. Definisi tentang buruk anak menurut ILO dalam konvensi 138 mengenai usia minimum untuk pekerjaan (1973) menyatakan : usia minimum...tidak boleh kurang dari usia untuk wajib belajar dan bagaimanapun juga, tidak boleh kurang dari 15 tahun. ${ }^{3}$ Maka secara global sudah ada konvensi bersama tentang aturan pekerja anak.Tetapi masalah ini secara global terus meningkat secara khusus di dunia ketiga. Dalam konteks Indonesia ada beberapa penyebab yang saling berkaitan satu dengan yang lain yaitu : (1). Kemiskinan; (2). gagalnya pendidikan; (3). Berkembangnya perekonomian informal; (4). Upah rendah; (5). Tidak adanya organisasi pekerja di sektor informal dan (6). Masih adanya adat atau sistem sosial yang membiarkan anak terlibat dalam pekerjaan sejak usia dini. ${ }^{4}$ Bradley memberikan beberapa faktor lain yang perlu dipertimbangkan sebagai penyebab buruh anak yaitu:

1. Ekonomi demi kepentingan sendiri: pemilik-pemilik pabrik yang melemburkan, membayar upah dibawah ketentuan dan memanfaatkan buruh anak-anak untuk mendapatkan keuntungan.

2. Sikap acuh tak acuh publik: politisi, media, organisasi non pemerintah dan para pencetus pendapat lainnya bersama-sama memperlakukan buruh anak tidak sebagai suatu pokok persoalan.

3. Kebijaksanaan publik: sumber-sumber yang tidak mencukupi pendidikan dasar dan kebijaksanaan-kebijaksanaan promosi eksport untuk mendukung perusahaan-perusahaan dan industri-industri tanpoa memperhatikan dampaknya yang kuat pada buruh anak.

3 Phyllis Kilbourn (editor), Children in Crisis : a new commitment (Batu : YPPII Dep. PAP, 2002),59

4 KSBI, KSPSI,KSPI, Pekerja Anak, Pendidkan Anak pekerja / Buruh, Skema bantuan dan Komite Sekolah, (Jakarta, 2007),9 
4. Kekurangan pemerintah: pengamat-pengamat buruh yang kurang mempunyai kekuasaan, keahlian, jumlah dan pertanggung jawaban untuk melaksanakan undang-undang mengenai buruh anak.

5. Korupsi Pemerintah: pejabat-pejabat pemerintah yang tidak hanya memanfaatkan tetapi dalam banyak hal secara pribadi mengambil keuntungan dari buruh anak.

6. Prasangka masyarakat: kelompok mayoritas yang menempatkan buruh anak diantara kelompok-kelompok yang kurang beruntung sebagai suatu hal yang wajar. ${ }^{5}$

Persoalan mengenai buruh anak adalah seperti benang kusuk yang harus diuraikan secara serius dan teliti.Karena anak-anak bekerja sebagai buruh dengan berbagai alasan bahkan kepentingan yang terselubung. Melihat fenomena ini maka hanya ada dua alternatif yang bisa dilakukan yaitu : menolong atau mengabaikan mereka. Tetapi sebagai kaum yang dipilih dan dipanggil oleh Allah maka seberkas cahaya terang itu harus kita pancarkan kepada anak-anak para buruh yang sudah tidak menentu arah dalam menjalani kehidupan ini. Nabi Yesaya menubuatkan bahwa buluh yang patah terkulai tidak akan diputuskanNya dan sumbu yang pudar nyalanya tidak akan dipadamkanNya. Ada banyak anak yang membutuhkan uluran tangan dan sentuhan kasih dari sesamanya.

\section{REFLEKSI TEOLOGIS}

Solusi apapun yang ditawarkan untuk menyelesaikan persoalan buruh haruslah didasarkan kepada kebutuhan tentang keadilan bagi mereka yang tertindas dan terlebih lagi adalah kebutuhan pendidikan anak.Alkitab menyebutkan betapa pentingnya pelayanan dan pendidikan kepada anak. Nasehat Amsal $22: 6$ " didiklah orang muda menurut jalan yang patut baginya maka pada masa tuanya ia tidak menyimpang dari pada jalan itu”. Pendidikan adalah salah satu aspek penting untuk menentukan arah masa depan manusia termasuk anak di dalamnya. Bahkan pola pendidikan harus di lakukan sejak anak-anak dan pola pendidikan bukan sekedar sebuah program biasa tetapi Alkitab mencatat bahwa pendidikan adalah perintah yang harus dilakukan secara berulang-ulang, terus menerus dalam segala situasi (Ulangan $6: 6-9$ ). Bahkan Rasul Paulus menulis surat kepada Timotius untuk supaya meningat pendidikan yang sudah diterima sejak kecil yaitu pendidikan kitab suci (2 Tim $3: 15)$.

Dengan mengacu kepada apa yang ditulis dalam Alkitab, maka pendidikan harus mendapat tempat yang sentral dan diperlukan peran orang tua dalam membantu dan melaksanakannya kepada anak. Akan tetapi dengan

5 Phyllis Kilbourn (editor), Children in Crisis ...,65-66 
semakin berkembangnya zaman pola pendidikan menjadi semakin beragam dan yang lebih memprihatinkan lagi pendidikan kadang hanya diukur dengan pola pendidikan formal yang menuntut begitu banyak pra syarat dan syarat yang akhirnya pendidikan menjadi sesuatu yang eksklusif dengan dibatasi oleh dinding-dinding pemisah kelas sosial dalam masyarakat.Pendidikan menjadi bahan komoditi yang hanya bisa dinikmati oleh sekelompok orang saja.

Jika kita melihat realita kehidupan para buruh dan secara khusus anakanaknya, maka pendidikan menjadi sesuatu yang langkah bahkan mustahil untuk di capai.Memang sesuatu yang sangat ironis terjadi dimana gereja memiliki sekolah-sekolah tetapi harganya terlalu mahal maka jemaat lokal pun sangat sulit untuk menyekolahkan anak mereka di sekolah yang adalah milik gereja sendiri. Jadi siapa lagi yang terpanggil untuk nasib pendidikan anakanak para buruh ?gereja dan orang Kristen harus memiliki panggilan Allah. Tuhan Yesus dalam Matius 28 : 19-20 memberitakan perintah tegas yaitu menjadi sekalian bangsa muridNya dengan cara mengajar. Disini jelas sekali bahwa betapa pentingnya peranan pendidikan dan itu berlaku bagi panta ta ethne (seluruh kaum).Yesus Kristus tidak pernah bersifat eksklusif hanya kepada kelompok tertentu. Selain itu dalam laporan Injil yaitu dalam Tulisan Markus 12 : 31 yaitu hukum penting kedua adalah mengasihi sesama. Maka semua orang dipanggil untuk mengasihi.Bahkan secara khusus Yesus memberi perhatian kepada anak-anak. Dalam laporan Matius 19 : 13-15, para murid mencoba menghalangi anak-anak datang kepada Yesus Kristus karena bagi mereka anak-anak buka merupakan bagian yang penting, tetapi Yesus bersikap terbalik dan berkata : Biarkanlah anak-anak itu, janganlah menghalangihalangi mereka..." Tuhan Yesus sangat peduli dengan anak-anak bahkan penekanannya dalam teks ini adalah merekalah (anak-anak) yang memiliki surga.Yesus ingin menjelaskan bahwa ketulusan, kejujuran, keterbukaan seperti sifat anak-anak adalah tanda untuk memiliki surga. Pertanyaannya adalah bagaimana jika ketulusan dan keterbukaan, kejujuran dihilangkan oleh karena masa kanak-kanak mereka dipaksa dan di eksploitasi ?Karenanya di butuhkan sebuah pastoral care bagi anak-anak dan hal itu dilandasi kepada sifat kasih sebagaimana yang Tuhan Yesus sudah nyatakan dan tunjukkan bahkan ketika Dia mengurbakan diri-Nya menjadi tebusan bagi orang berdosa.

Dalam tulisan Rasul Paulus kepada jemaat di Roma tentang bagaimana Allah menunjukkan kasihNya kepada manusia berdosa tanpa ada sumbangan sedikitpun dari manusia.Allah secara aktif dan rela memberi diri-Nya menjadi tebusan bagi orang berdosa.Dalam Roma pasal 5 ayat 6,8,10 dicatat tentang bukti kasih Allah yang sejati dan waktu pelaksanaan kasih itu.Istilah "waktu kita masih lemah (ay 6), ketika kita masih berdosa (8), ketika kita masih seteru (10), ini menunjuk kepada status manusia di hadapan Allah dan kemudian menjadi sasaran kasih Allah.Jadi, kasih Allah tidak pernah disebabkan oleh apapun tetapi semua adalah inisiatif Allah semata. Maka implikasinya adalah 
semua orang yang mengaku percaya dan telah ditebus harus peduli dan berbagi dengan orang lain karena Allah telah peduli lebih dahulu kepada mereka. Sehingga pastoral care bukan hanya semacam kegiatan sosial semata tetapi suatu tanggungg jawab rohani dengan tujuan mewujudkan kesejahteraan sosial sesama umat manusia.

\section{Model dan Metode Pelayanan kepada anak-anak buruh}

Mencermati fakta yang terjadi dilapangan tentang kompleksitas masalah para buruh yang kemudian memberi pengaruh kepada komuitas buruh dalam hal ini adalah keluarga maka dibutuhkan pola dan pendekatan pelayanan pastoral yang relevan bagi kehidupan para buruh.Dalam kajian yang singkat ini penulis menggunakan pendekatan komunitas yaitu dengan model pelayanan yang berbasis pendidikan yang dimulai dari orang tua. Metode pendekatan yang digunakan adalah kegiatan analisis sosial dan refleksi teologis yang bersumber kepada: (1). Tradisi Kristen, (2) Pengalaman, (3). Budaya. Tahapan dalam pelayanan pastoral komunitas (basis para buruh) menggunakan metode siklus analisis, refleksi teologis dan $\mathrm{aksi}^{6}$ adalah sebagai berikut:

1. Tahapan Berkontak. Masuk dalam komunitas para buruh, berinteraksi dan melakukan observasi. Tahapan ini dimulai dengan pendekatan dan perkenalan. Berita sudah diperoleh, secara fisik sudah ketemu. Hal ini memungkinkan adanya banyak informasi yang diperoleh tentang situasi budaya (situasi sosial, norma, nilai-nilai dan hubungan antar etnik), sehingga informasi tentang problematika untuk pelayanan pastoral bisa ditemukan baik secara pribadi maupun komunitas. Dalam tahapan ini diperlukan sikap yang kritis untuk mengkaji dan menganalisa situasi. Pendekatan dimulai dari orang tua dengan mencoba berkenalan atau berkontak.

2. Tahap menerima. Dalam bagian ini sudah terjalin hubungan yang lebih akrab dan muncul sikap saling menyetujui. Sehinga sangat memungkinkan untuk terciptanya dialog-dialog yang bersifat andragogis antara para buruh dan pelayan serta seluruh komunitas yang memungkinkan dibangunnya suasana reflektif dan interaktif dengan membawa sumber-sumber yang kemudian disepakati dan disetujui secara bersama khususnya dalam hal spiritual. Dalam hal ini para pelayan harus memiliki keyakinan bahwa pesan yang disampaikan melalui sumber itu dapat dipercayai. Ini berarti pesan harus didukung oleh fakta, dan argumen atau alasan yang kuat bahkan keyakinan dari

6 Penulis meminjam metode siklus dalam pelayanan pastoral bagi para buruh melalui tulisan D. Momongan pelayanan pastoral bagi pekerja MIGRAN 
pembawa pesan terhadap pesannya. Memberi keyakinan kepada orang tua terlebih dahulu dan kemudian kepada anak-anak mereka.

3. Tahap berinteraksi.Sudah ada interaksi yang saling bergantung satu dengan yang lain. Sudah ada tindakan konkrit yang didukung bersama artinya tanggapan positif dari komunitas sudah ada sehingga mendorong kepada suatu tindakan bersama untuk melakukan transformasi.

Bentuk pastoral komunitas ini capaian utamanya adalah komunitas yang kemudian berlanjut kepada kelompok-kelompok kecil / rumah tangga yang kemudian berlanjut kepada anak-anak.Komunitas yang dimaksud disini adalah lebih spesifik yaitu kelompok anak-anak para buruh kasar. Sebagai satu komunitas mereka terpanggil untuk berjuang bersama, saling memperhatikan, menolong, menguatkan, berbagi, peduli terhadap semua hal yang dasarnya adalah membangun spiritualitas dalam bentuk pendalaman Alkitab secara berkala, sharing life dan mencari solusi bersama dalam terang firman Allah, yang kemudian hal ini mempengaruhi segala sisi hidup mereka, termasuk etos kerja orang tua serta sistem sosial secara menyeluruh dalam komunitas buruh.

\section{Bentuk dan Aspek pelayanan}

Pelayanan pastoral dalam model pastoral komunitas yang paling efektif adalah pendampingan.Pendampingan disini bukan sekedar sebuah pendampingan biasa tetapi pendampingan dalam pengertian kehadiran dalam komunitas buruh secara tetap, intensif dan kreatif.Pola pendampingan pastoral acuan modelnya adalah Yesus Kristus. Dia melayani, mengajar dan sangat kreatif dalam memberikan pengajaran-Nya dengan menggunakan perumpamaan untuk menghancurkan sistem pemikiran yang kakuh dan salah bahkan sebagai pendamping, Yesus Kristus menggunakan sistem pendamping sebagai Hamba "Aku datang bukan untuk dilayani tetapi untuk melayani" hal ini terimplementasi ketika Yesus Kristus melakukan pembasuhan kaki para murid. Bahkan Dia rela mati bagi umat manusia yang adalah domba gembalaan-Nya.

Sebagai satu komunitas yaitu kelompok buruh, mereka memerlukan pendamping/pastor atau gembala yang berani melakukan terobosan, membina, merawat, mengayomi, mengerti seluk beluk problematika sosial dan rohani dan sikap yang siap berkorban tanpa pamrih serta hati yang mengasihi anakanak karena jika pelayanan pendampingan hanya kepada orang tua maka anak akan terlantar, jadi perlu ada kecakapan khusus dari gembala untuk bagaimana melayani anak-anak bukan hanya sekedar "berdongeng" atau memberikan hadiah dan pulang.

Dalam mencapai keefektifan dan keberhasilan sistem pendampingan ini maka perlu dilihat beberapa aspek penunjang yang antara lain : 
1. Aspek pemberdayaan. Dalam bagian ini dimensi yang dilihat adalah pemahaman dan kesadaran tentang realitas ekonomi dan tantangan yang dihadapi secara khusus melihat faktor eksternal dan internal.

2. Aspek Edukasi yaitu memberikan pendidikan secara formal dan informal baik kepada buruh (orang tua) maupun kepada anak-anak.

3. Aspek Advokasi yaitu memberikan perlindungan hukum dan pembelaan hukum terhadap tenaga kerja buruh dan juga terhadap anakanak mereka, sehingga dapat mencegah perlakuan terhadap anak yang tidak sesuai dalam hal ini menjadikan anak sebagai buruh.

4. Aspek kesejahteraan yaitu pemenuhan kebutuhan fisik dan dan psikologis. Memiliki rumah layak tinggal dan mampu membayar biaya pendidikan anak dengan cara pemberian upah yang pantas.

5. Aspek Garansi yaitu para buruh bekerja pada perusahaan yang memiliki jaminan kerja yang jelas dari pemerintah atau semua tempat dan jenis pekerjaan apapun yang melibatkan buruh harus resmi di bawah pengawasan pemerintah.

6. Aspek Publikasi dan Dokumentasi yaitu sebuah lembaga khusus yang meliput dan mencatat serta mendokumentasikan semua kegiatan buruh secara eksternal dalam bentuk buletin atau majalah yang khusus menyoroti buruh. Serta kegiatan internal buruh seperti pentas seni dan budaya yang melibatkan anak-anak para buruh dan kemudian di publikasikan keluar sehingga dapat memberikan cara pandang baru terhadap kehidupan para buruh.

\section{Elemen-elemen pendukung pelayanan Pastoral}

Untuk dapat menerapkan bentuk pelayanan komunitas secara khusus bagi anak-anak para buruh dibutuhkan elemen pendukung pelayanan yaitu :

1. Perlu adanya pemahaman tentang pekerjaan sebagai buruh serta problematika-problematika di dalamnya sehingga memberikan kesadaran kepada orang tua untuk tidak melibatkan anak sebagai buruh.

2. Pembuatan rumah "singgah" yaitu disiapkan khusus satu tempat khusus untuk anak-anak dalam melakukan aktifitas mereka serta menyiapkan menyiapkan guru-guru yang berkompeten bukan hanya sekedar guru sukarela.

3. Melakukan lobby dengan perusahaan untuk anggaran sosial kemasyarakatan diarahkan kepada kegiatan anak-anak sehingga orang tua bisa konsentrasi dalam bekerja (menciptakan etos kerja yang baik).

4. Menyiapkan sponsor khusus untuk biaya pendidikan formal anak-anak para buruh. Disini diperlukan kelompok pendukung dari segala bentuk organisasi ataupun lembaga manapun. 
5. Melakukan kerjasama dengan para dokter untuk memberikan perhatian dan pengarahan kepada orang tua dan anak tentang pentingnya kesehatan secara khusus gizi anak atau menghadirkan para ekonom, pakar hukum, psikolog yang memiliki panggilan untuk memberikan sumbangsih, saran dan menjadi fasilitator bagi anak-anak para buruh.

6. Pengaturan program pelayanan yang efektif, dinamis dan relevan.

\section{KESIMPULAN}

Problematika buruh di Indonesia memang sangat kompleks. Tetapi ini tidak berarti bahwa hal ini didiamkan saja atau "let it go with the wind". Sebagai anak bangsa kita harus meberikan perhatian khusus terhadap hal ini secara khusus kepada nasib anak-anak para buruh. Jika kita hanya berharap kepada satu instansi saja dalam penanganan anak-anak para buruh, maka di waktu yang akan datang Indonesia akan menjadi negara "pengeksport" tenaga buruh terbesar dan itu adalah buruh anak. Karena itu gereja sebagai lembaga spiritual yang memiliki pengaruh besar harus mengambil peran dalam upaya mencegah perlakuan yang tidak layak terhadap anak-anak para buruh.

Tulisan ini masih sangat sederhana dan perlu dikaji secara ilmiah lagi secara khusus model pendekatan karena model pendekatan biasanya tergantung konteks dimana para buruh berada. Tulisan ini hanyalah langkah awal untuk menstimulir semua mereka yang merasa diri terpanggil sebagai pelayan Tuhan utnuk memikirkan pelayanan secara holistik atau memikirkan dan memberikan sumbangsih bagi pelayanan pastoral holistik.Konsep bentuk pelayanan pastoral ini masih perlu masukan lagi demi keefektifan pelayanan pastoral kepada anak-anak para buruh. Serta bagaimana cara pemberdayaan anak-anak para buruh yang maksimal untuk mencegah kegiatan buruh anak. Anak adalah generasi penerus bangsa termasuk anak para buruh.Mereka berhak untuk mendapat perlakuan dan pelayanan pastoral bahkan mereka juga berhak untuk menjadi agen perubahan di bangsa ini. 


\section{DAFTAR PUSTAKA}

Kennedy, James dan Newcombe, Jerry

1999 Bagaimana Jika Yesus tidak pernah lahir, BATAM Interaksara

Kilbourn, Phyllis (editor),

2002 Childrenin Crisis : a new commitment Batu : YPPII Dep. PAP

Tong, Stephen

2000 Membesarkan anak dalam Tuhan, Jakarta, LRII

2007

KSBI, KSPSI,KSPI, Pekerja Anak, Pendidkan Anak pekerja / Buruh, Skema bantuan dan Komite Sekolah, Jakarta 